\title{
The Corner of the Living: Ayacucho on the Eve of the Shining Path Insurgency \\ Miguel La Serna.
}

\section{La esquina de los que viven: Ayacucho en vísperas de la insurgencia de Sendero Luminoso.}

\section{A esquina dos que vivem: Ayacucho na véspera do surgimento do Sendero Luminoso.}

Chapel Hill, The University of North Carolina Press, 2012, 304 páginas ISBN: 978-0807872192

\section{RESEÑA \\ Javier Puente \\ Georgetown \\ University, Washington D.C., Estados Unidos \\ jp452@georgetown. edu}

DOI

10.3232/RHI.2013.

V6.N2.10
Miguel La Serna ha publicado un libro extraordinario, cuyos límites van más allá del título. El libro está basado en la disertación doctoral que el autor defendió en la Universidad de California, San Diego, bajo la dirección de Christine Hünefeldt. Varios de los temas y discusiones que el libro desliza y desarrolla, sin embargo, están formados por la colaboración intelectual de una pléyade de académicos interesados en temas políticos, rurales y raciales en otras latitudes de América Latina; esto hace que The Corner of the Living adquiera una dimensión hemisférica escapando del riesgo de caer en un ámbito historiográfico insular. La Serna -profesor asistente en la Universidad de Carolina del Norte, Chapel Hillcolabora con una literatura transnacional sobre problemas relacionados con el pasado campesino de la región y con su historia durante una era de revoluciones y contrarrevoluciones.

The Corner of the Living es fundamentalmente un estudio local, una examinación exhaustiva de dos microcosmos rurales, dos villas geográficamente próximas pero históricamente distantes, ambas ubicadas en el departamento de Ayacucho. La primera es Chuschi, una comunidad campesina ubicada en la provincia de Cangallo que pasó trágicamente a la posteridad por ser el lugar en el que Sendero Luminoso inició su lucha armada en 1980. Parte de la tragedia de Chuschi es haberse convertido en un nombre tan frecuentemente mentado con un signo de sangre, y sin embargo haber permanecido tanto tiempo relativamente oculta en los anales de la historia -punto resuelto por el libro de la Serna. La segunda es la villa de Huaychao, ubicada en la provincia de Huanta, una región cuya tradición histórica es asociada con el pasado lquichano, un pasado de guerrillas que cobraron notoriedad durante el conflicto con Chile en el siglo diecinueve, y que sirve para generar una etiqueta étnica centrada en una identidad de movilización y resistencia. Ambas villas tuvieron papeles decididamente diferentes durante el conflicto armado interno: mientras que Chuschi pareció ser más receptiva frente al mensaje de radicalización política y revolución propalado por Sendero Luminoso, Huaychao resistió más o menos activamente la presencia de huestes senderistas en su región. 
La pregunta central de The Corner of the Living intenta explicar esta tensión de proximidad y diferencia. Si ambas son comunidades indígenas y campesinas ubicadas en regiones relativamente cercanas, con experiencias de vida marcadas por la pobreza, la migración y una creciente diferenciación interna, ¿por qué tuvieron una actitud política distinta frente al mismo evento? Para responder esta pregunta, La Serna se embarca en una discusión sobre el siglo veinte rural en Ayacucho, atendiendo a cuestiones de carácter material, económico, social, y hasta ecológico y medioambiental para entender ese otro sendero que recorrieron comunidades como Chuschi y Huaychao en décadas previas al conflicto, y que desembocaron en un camino de violencia.

La lista de repositorios y archivos que sostienen la investigación evidencia la fractura del registro institucional del problema campesino que cualquier investigador interesado en temas rurales enfrenta para reconstruir estas narrativas locales holísticas. The Corner of the Living además compensa esta fractura complementando su trabajo archivístico con una labor etnográfica sensitiva y delicada, que reconstruye la vitalidad y cotidianidad de un pasado inmediato en las localidades en cuestión.

El libro posee una estructura temático-cronológica y se puede decir que se divide en dos grandes partes. La primera parte -capítulos uno, dos y tres- explora teórica y empíricamente los problemas asociados con el sentido de justicia y los orígenes del conflicto social en el seno de comunidades indígenas hacia mediados del siglo veinte. También considera las relaciones sociopolíticas y económicas entre diferentes comunidades indígenas durante la oleada de movilizaciones campesinas de la década de los sesenta y en el período previo a la reforma agraria militar de 1969. De igual manera, analiza la aceleración de procesos de diferenciación interna y el aumento de antagonismos que trascienden relaciones de clase y tensiones raciales antes y durante el Gobierno Revolucionario de las Fuerzas Armadas (1968-1980). La segunda parte capítulos cuatro, cinco y seis- cubre directamente el periodo de violencia política explorando las raíces del apoyo inicial a Sendero Luminoso y el surgimiento de la resistencia campesina frente a este movimiento, y los cambios y continuidades al interior de Chuschi y Huaychao luego del conflicto armado interno. Finalmente, la conclusión ofrece una reflexión sobre el estado presente de las comunidades campesinas en el Perú -extendiendo parte de las reflexiones a otras regiones de América Latina-y la vigencia del conflicto entre poblaciones indígenas, ideologías y estados en diversas latitudes.

The Corner of the Living desarrolla con éxito buena parte de las hipótesis que propone. Sin hacer un recuento de todas, quisiera mencionar algunas que deberían llamar la atención. La primera tiene que ver con la preeminencia del sentido de poder local y justicia para entender las raíces del conflicto armado interno. La Serna nos muestra el alto grado de organización política y social al interior de las comunidades y de qué manera su institucionalidad, o la ausencia de ésta, determinaron sus posiciones posteriores frente al radicalismo de la prosa maoísta. Curiosamente, mucha de esta institucionalidad comunal fue promovida, auspiciada, y sancionada por el estado peruano a lo largo del siglo veinte, el mismo estado que luego colocó a las comunidades entre dos fuegos. 
La segunda hipótesis tiene que ver con un debate todavía tácito sobre la relación de causalidad y consecuencia entre el Gobierno Militar y el conflicto armado interno, episodios unidos por una secuencialidad temporal y espacial -ambos cubren conjuntamente poco más del último cuarto de siglo veinte, y se desarrollaron profundamente centrados en el campo y el universo rural peruano. Hasta el momento esta relación había sido planteada de manera un tanto dicotómica: o bien el Gobierno Militar y su reformismo agrario había constituido una suerte de caja de pandora de la que Sendero Luminoso habría sido uno de los tantos males que logró escapar, o bien la reforma de 1969 había desterrado elementos claves -la figura del gamonal, por ejemplo- que evitaron que Sendero Luminoso pudiera desenvolverse con una mayor acogida de parte de las pauperizadas comunidades campesinas. The Corner of the Living rompe esta dicotomía presentando una narrativa matizada, una visión menos institucional del reformismo castrense, una mirada "desde abajo" donde los campesinos buscan construir pactos sociales con otras comunidades, hacendados, y el Estado en aparente búsqueda de una autonomía comunal que, por ejemplo, privilegia la privatización frente a la cooperativización. Es la construcción y la desestimación de estos pactos lo que puede explicar con más acierto el espacio semántico de los discursos políticos radicales y el de la misma violencia.

Finalmente, La Serna desliza otras ideas que merecen futuro tratamiento y más atención. Por ejemplo, resultaría interesante atender a las relaciones entre comunidad y estado en Ayacucho a inicios del siglo veinte, particularmente cuando la administración de Augusto B. Leguía (19191930) se vuelca sobre la población indígena, reconstituyendo y sancionando la legitimidad de las comunidades y orquestando lo que parece ser un proyecto de ingeniería social que marcó el derrotero de la nación peruana por el resto del siglo. De igual modo, pese a que el valor del libro está en la escala que se usa para deconstruir y problematizar narrativas nacionales, los intentos por enganchar lo local con cuestiones hemisféricas -por ejemplo, el rol que juegan las políticas de Guerra Fría en el desarrollo de discursos insurgente y contrainsurgentes- son pocos y se frecuentemente se limitan a comparaciones un tanto descontextualizadas. Un último comentario punto tiene que ver con la cuestión de género: es interesante que La Serna limite su discusión sobre género y patriarcalismo a varios acápites salpicados en diferentes capítulos y que no sea más medular en la estructura de su investigación, siendo que es uno de los componentes más distintivos y únicos de su investigación.

En suma, The Corner of the Living es un libro sólido, provocador e innovador, que va a merecer mucha atención en la academia, y que esperamos pueda ser traducido al español prontamente para una discusión más fructífera sobre su valor historiográfico. 